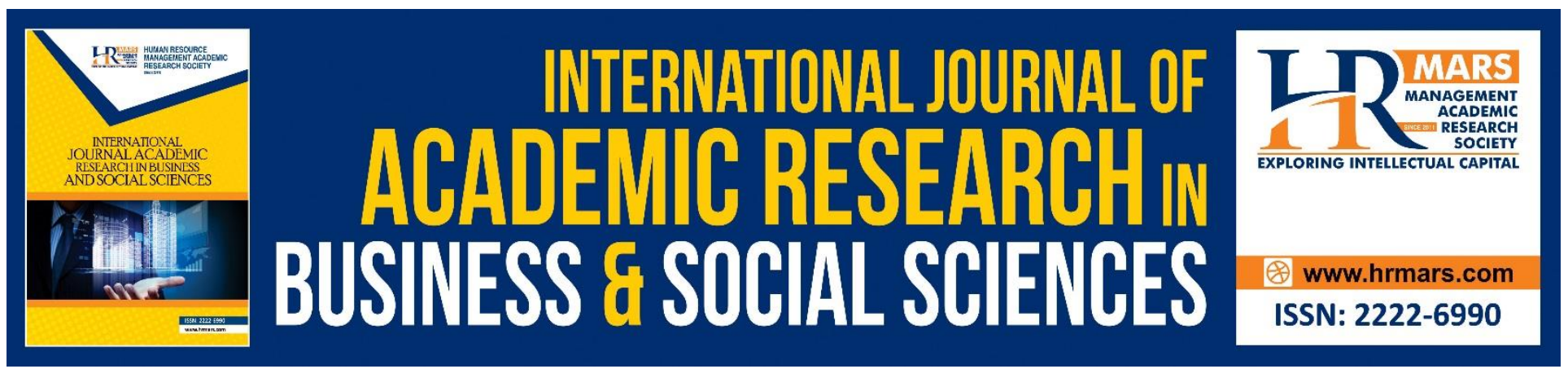

\title{
Motivation Role of the Operational Manager's Opportunities to School Business Performance
}

Samsu Haji Ewang, Juliana Haji Osman@ Zainal Abidin, Mohamad Aqil Rustam

To Link this Article: http://dx.doi.org/10.6007/IJARBSS/v10-i9/7727

DOI:10.6007/IJARBSS/v10-i9/7727

Received: 08 June 2020, Revised: 04 July 2020, Accepted: 20 August 2020

Published Online: 16 September 2020

In-Text Citation: (Ewang, Abidin, \& Rustam, 2020)

To Cite this Article: Ewang, S. H., Abidin, J. H. O. Z., \& Rustam, M. A. (2020). Motivation Role of the Operational Manager's Opportunities to School Business Performance. International Journal of Academic Research in Business and Social Sciences. 10(9), 288-299.

Copyright: @ 2020 The Author(s)

Published by Human Resource Management Academic Research Society (www.hrmars.com)

This article is published under the Creative Commons Attribution (CC BY 4.0) license. Anyone may reproduce, distribute, translate and create derivative works of this article (for both commercial and non-commercial purposes), subject to full attribution to the original publication and authors. The full terms of this license may be seen

at: http://creativecommons.org/licences/by/4.0/legalcode

Vol. 10, No. 9, 2020, Pg. 288 - 299

http://hrmars.com/index.php/pages/detail/IJARBSS

JOURNAL HOMEPAGE

Full Terms \& Conditions of access and use can be found at http://hrmars.com/index.php/pages/detail/publication-ethics 


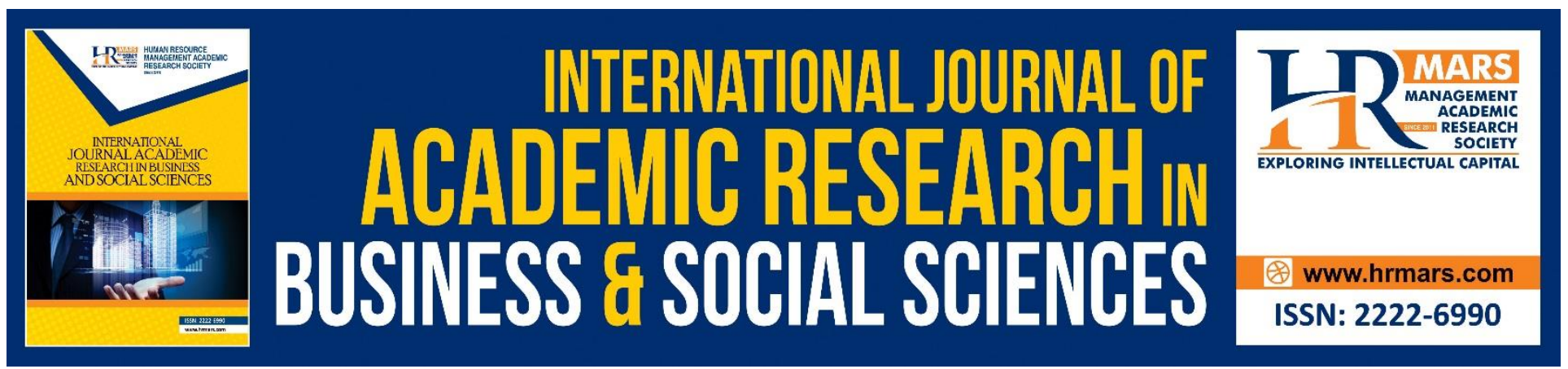

\title{
Motivation Role of the Operational Manager's Opportunities to School Business Performance
}

\section{Samsu Haji Ewang, Juliana Haji Osman@ Zainal Abidin, Mohamad Aqil Rustam}

Faculty of Management and Economics, Universiti Pendidikan Sultan Idris, Tg. Malim, Perak. Malaysia

Email: samsue20@yahoo.com.my

\begin{abstract}
The school cooperative movement in Malaysia has shown an increasing trend in the annual income, but there are still school cooperatives that have failed to achieve the proper performance. The purpose of this study is to determine the influence of the motivation of the cooperative manager's work on the success of the school cooperative business. The business success factors in this study are based on McKinsey 7S Model and Marketing Theory. Quantitative approaches with non-experimental designs were used in this study. The sample selection was conducted on a stratified random sample (layared) involving 211 Co-operative Board Members from school teachers from all over Sabah. The instrument used was a modified questionnaire from several previous researchers related to the factors of school cooperative success. Data were analyzed using descriptive and inference analysis. Descriptive analysis described respondents' backgrounds and school cooperative backgrounds, while inference statistics were analyzed using the Structural Equation Model (SEM), which described the effect of all the independent variables on the dependent variables. The findings show that work motivation factors have a significant relationship with the success of the school cooperative business. The findings of the study show that work motivation factors have an impact on cooperative performance. The implications of this study indicate that motivational factors of managerial work affect the performance of school cooperative business in Malaysia.
\end{abstract}

Keywords: Motivation, Work, Performance, Cooperative and Business.

\section{Introduction}

Motivational discipline generally studies the causes of individual behavior. It can be regarded as a direction in action. The definition of motivation is technical and non-technical. Its technical definition summarizes motivation as individual behavior driven by psychological processes. Non-technical definitions focus on the extent to which individuals work hard to perform their tasks. Another definition defines motivation as the perspective of an individual who uses his or her strength to reach the goals set by the organization (Zafir et al., 2012). While Kotler and Keller, (2016) motivation is the impetus for a person to take action. The process of motivation begins when an individual is aware or 
aware of a need that is not being met. Bartol and Martin (1998) have classified key theories of motivation into three categories: needs theory, cognitive theory, and reinforcement theory. The most popular theory of necessity was Abraham Maslow's theory of necessity (Maslow, 1970) and it was known as Maslow's motivational theory of hierarchical necessity. The hierarchy includes five basic levels of need, which must be met in succession.

While managers are defined as human resources in an organization responsible for managing and operating the organization. It is also the individual who ensures employees perform their tasks efficiently and effectively (Zafir et al., 2012). Managers and motivations are two closely related elements. Understanding the term motivation and its content is particularly important for organizational managers as it tells us something that is clearly behind the actions and behaviour of humans. In this study (Dimas, 2011), it was found that the influence of work motivation significantly affected the job satisfaction of individuals. In another study by Agus (2006); Andjarwati (2015); Mustapa Kamal et al. (2015); Syafri et al. (2015); Prasetyaningrum (2020); Kasino \& Indrayanti (2020) has shown that work motivation is a good mediator of positive and significant influence on work.

A motivated manager will focus on all the responsibilities assigned to him. Managers have a responsibility to create the right climate in which employees can grow to their full potential (Eravala et al., 2019). Failure to provide such a climate would theoretically increase employee frustration and could result in lower performance, lower job satisfaction, and increased organizational productivity (Rafikul \& Ahmad, 2008). The study of Syafri et al. (2015); Mustapa Kamal et al. (2015), found that motivation has a positive relationship with individual job performance that directly influences the concentration of responsibility in performing tasks.

\section{Objectives}

The purpose of this study was to determine whether factors that motivate the work of school cooperative managers affect the performance of school cooperative business in Sabah. Malaysia.

\section{Literature Review \\ The Role of Motivation}

The Role of Motivation Employee engagement is essential for every business to help maintain a positive attitude among team members towards their work and organization, playing a key role in increasing productivity (Owens, 2014). Workers with high internal motivation will always work hard without being forced or directed to carry out their responsibilities (Chiang \& Jang, 2008). In theory $Y$ explains that employees who have type $Y$ Theory will work on their own without the supervision or supervision of their superiors. This type of Theory $\mathrm{Y}$ is a type that is aware of its job duties and responsibilities. In the study (Antonio's, 2014), four leaders who adopted the "inspirational" model of staff motivation along with nine of their employees who participated in the survey positively impacted their staff performance. The leaders show that most workers continue to work hard for the past two years, as they get higher job satisfaction and increase productivity. Likewise, all employees show that employees in the firm are in harmony, their jobs are attractive and that there is also increased trust and better communication between them and senior management teams. This keeps the spirits high and reduces their mistakes. Therefore, high motivation is essential for a cooperative manager to prevent productivity decline. The study of Azman et al. (2016) found that entrepreneurs are less motivated and lack confidence in their business. 
Working in groups is important for higher productivity. The motivational theory of three needs by McClelland (1985) argues that one aspect of the three needs is the need for relationships. It is a need to be liked and accepted by others. In other words, individuals like cooperation and understanding and work in groups to achieve organizational objectives. The study of Mujah et al. (2011), factors that increase employee motivation not only include pay and bonuses but also have good friends and proper work facilities that lead to high effectiveness. It is through this cooperative attitude that the cooperatives help the school to carry out their activities. Co-workers in organizations are important in influencing workers' attitudes towards their responsibilities (Prasetyaningrum, 2020). Co-workers who show a cooperative attitude and help one another will give employees satisfaction if it does otherwise would have a negative impact on Luthans' (1998) employee satisfaction. Further, the division of duties and responsibilities among cooperative leaders and teamwork facilitates the planning that is implemented effectively (Rohaida \& Razaleigh, 2014). This is in line with the principle of co-operation that prioritizes cooperation and also conforms to the goals and identity of the cooperative established.

In an organization a leader must allow subordinates to voice their opinions. Two-way interactions are crucial to helping organizations access information to address any weaknesses that may exist (Pauline, 2017). This is in line with the principle of cooperatives that allows members to participate directly in contributing to the idea of ensuring the co-operation of their respective cooperative schools by the By-Laws (UUK). Members, Corporation Boards Members (CBM) and comanagers can express their views openly with regard to the views and proposals for the development of the cooperative especially at the annual general meeting of the cooperative. No one shall be barred from expressing his views or motions as long as they do not contravene the By-Laws (UUK) and the Cooperative Act (1993). This statement is in line with the findings of Lasrado et al. (2017), that employee participation in the employee suggestion system (ESS) is important as a factor in the success of an organization. The study of Fasasi et al. (2016) is also in agreement with the findings of the study which suggest that employees should be involved in decision making especially in expressing dissatisfaction with the organization. This is because the involvement of the workers either provides a perspective or as a key informant in the idea of shaping the success of the cooperative.

Motivated employees will be better prepared to do the job they are given. The higher the motivation they have, the higher the productivity they will generate (Nimusima \& Tumwine, 2017). Managers who receive internal motivation will act on their own to better manage their work especially in their organizational activities (Antonios, 2014). They directly do not require serious supervision because their motivation and desire to work is not based on external rewards (Ankli et al., 2014).

The ability of a school cooperative to move further and further than in the early stages of the establishment of a cooperative must be led by a cooperative leader who is always committed to cooperative identity, cooperative governance and cooperative legislation and adapts its approach from time to time. In other words, they should be cooperative souls and always be dedicated to conducting school cooperative activities (Rohaida \& Razaleigh, 2014). 
CBM and the management of the cooperative should give full attention to the business activities of the school cooperative, only those who are interested and have a positive attitude towards the cooperative can give such commitment (Abdul Fatah, 2016). Productivity improvement not only depends on customer service, technology, marketing strategies and other factors but it also depends on the motivation of the employee to perform the job (Rafikul \& Ahmad, 2008). This finding is in line with the findings of Coda et al. (2017), who studied small business owners in Sao Poulo Brazil found that motivations for small business owners are also important factors in their business performance. Only high-motivated workers will carry out their responsibilities diligently despite their many obstacles.

\section{Cooperative Success}

A cooperative is a business entity that is established to generate profits for the benefit of its members based on the concept of cooperation and operating in accordance with its own concept. This is in accordance with the Co-operative Societies Act 1993 which defines co-operatives as 'an organization composed of individuals and its aim is to enhance the economic interests of its members in accordance with the principles of co-operation'. It is the responsibility of the members of the Cooperative Board to be the supreme body of the management of the cooperative to plan strategic activities to achieve this goal in accordance with the by-laws approved at any General Meeting of the cooperative. There are several ways to evaluate the success of a cooperative, depending on the purpose of the study. Based on previous studies, several researchers have evaluated cooperative performance based on cooperative leadership ("Peruncitan dan Pemborongan' di Norge Coop, Oslo, Norway", 2014) cooperative management (Zeeta et al., 2014) retail business (Sharif Rohaya et al., 2013, education and training (Alhafidz et al., 2015) CBM school competence (Jamilah et al., 2012). However, in a report by the International Co-operative Alliance (2017) outlined several guidelines related to the economic success of a cooperative;

a) Social trust and capital

b) The commonality and mutual power among the members Income equality

c) Business environment in general

d) Good governance

e) The notion of corruption

f) The level of democracy

g) The legal and tax systems that take into account the specific nature of the cooperatives without giving them unreasonable treatment

h) Access to markets, capital, general support services, training programs, information, and public tenders

i) Opportunities for integration and vertical and horizontal networks Freedom to pursue economic and social objectives

Jamilah et al., (2012) study of CBM 100 Grade A school cooperatives using the Mckinsey 7S Model as a school cooperative success factor found that Skill is a key factor contributing to school cooperative success which is a factor in members' understanding of co-operation and emphasis on the development and education aspects of management and administration. The second factor is the cooperative support element of the cooperative's activities. The study also found that the co-requisite competency factor for CBM school cooperatives is financial management. 
INTERNATIONAL JOURNAL OF ACADEMIC RESEARCH IN BUSINESS AND SOCIAL SCIENCES Vol. 10, No. 9, 2020, E-ISSN: 2222-6990 @ 2020 HRMARS

The McKinsey 7S model has to do with cooperative success factors that contain seven key elements such as:

1) Strategy Style (Organizational Leadership Style)

2) Share value (Structure of how the organization is organized)

3) System (System, policy applied)

4) Structure (Structure of how the organization is organized)

5) Staff (Members or employees of the organization)

6) Skill (Management skills and competencies)

The study of Jamilah et al., (2012) found that the elements of the McKinsey 7S Model have similarities to the factors that success in a cooperative can be adopted by school cooperatives in the study. Therefore, this study has also established this model as the main guide along with several other theories. However, in this study only a few factors were taken as the variables of study based on the reading of the literature review and on the suitability of the cooperative as a business unit as well as the unit under the co-curricular activities of the school.

One of the factors that is considered in measuring the success of the cooperative by the Malaysian Cooperative Commission (MCC) is the number of members increasing over the three years. Therefore, co-managers should run more promotions to encourage more people to join the cooperative (Bazilah et al., 2013). The ever-increasing number of members will provide more support for consumers who are ready to buy a product or cooperative product. This is strength of the cooperative entity compared to other business entities.

The success of the cooperative depends largely on the support of members, without the support of the planned activities it will not succeed (Rahimah, 2011). Cooperatives are formed by the unity and agreement of members who want to work together to run this business in accordance with the principles of the cooperative (Mohamad \& Ahmad, 2017). Any cooperative activity to be carried out should receive the support of the members (Karunakaran et al., 2011). Related activities may be canceled if they have a majority opposition from members especially at the general meeting. In the study of Rahimah and Noranita (2014), it was found that one of the factors of cooperative success is the strong support of the members. This statement is also supported by Zamri (2012) that the CBM should foster a culture of cooperation in fostering the involvement of members in each activity. It can also strengthen cooperative governance by strengthening members' roles and responsibilities and enhancing bilateral relations between CBM and board members.

The support of the school especially the principals as administrators are very important to the success of the school cooperatives. A number of studies have been conducted and it is found that Principals can be a catalyst for a school's success. There are many successful school cooperatives because their Principal provides support, understanding and involvement directly in the development and development of school cooperatives (Abdul Fatah, 2016). The role of students as key consumers in purchasing products and using the services offered by the cooperatives is also an extremely demanding form of support to ensure that the cooperatives can continue to succeed. This is because students make up $80 \%$ of the total number of school cooperatives (Mohamad \& Ahmad, 2016). Likewise, co-managers who are not only the main movers but also the main customers of the school co-operatives, without the support of the managers who are willing to sacrifice their time to manage 
INTERNATIONAL JOURNAL OF ACADEMIC RESEARCH IN BUSINESS AND SOCIAL SCIENCES Vol. 10, No. 9, 2020, E-ISSN: 2222-6990 @ 2020 HRMARS

the co-operatives, surely, the school co-operatives will not be able to continue their activities (Mohamad \& Ahmad, 2017). Therefore, strong support from all the school community is essential to ensure that the cooperatives can continue to grow as expected by the MOE and ANGKASA.

The practice of integrity in the co-management of special cooperatives to the CBM is essential to ensure the co-operation of the cooperative business. Incidents of shoplifting in school cooperative shops often occur without proper supervision by the management (Mohamad \& Ahmad, 2016). Likewise, the high integrity of CBM is highly demanded in order to increase the members' trust in the cooperatives. This will also guarantee the success of the cooperative to continue to be a successful cooperative (Rosmimah et al., 2011). Thus, transparent democratic control and practices can bring success to a society (Karthikeyan, 2011). High-integrity CBM will have a good work ethic that will directly satisfy members of the service and will be ready to continue using the services provided by the cooperatives ("Peruncitan dan Pemborongan' di Norge Coop, Oslo, Norway", 2014). Studies have also shown that the lack of integrity among CBM is also a key factor in cooperative problems to succeed, the lack of accountability to accountability has made many cooperatives unable to survive (Ruziana \& Zurina, 2015). In a report by the International Co-operative Alliance (ICA), (2017) found that the level of corruption seen in a country is closely linked to cooperative performance. The increase in corruption seen may indicate a deteriorating constellation for the cooperatives. Therefore, the high integrity of the CBM who have been entrusted by the members is highly demanded to ensure that the management of the school co-operatives in particular will continue to be successful.

The support of the MCC as a cooperative performance monitor as a whole should ensure that school cooperatives registered as business functions make business activities a priority, and then list the courses that the cooperative needs by recommending to the MCC to carry out the course. MCC should also provide technical assistance by facilitating co-operation with the parties involved in business activities (Najma et al., 2015). In addition, to enhance the performance of cooperatives through training, MCC and MKM need to constantly monitor and monitor their performance in academic and educational areas which are key activities, so as not to deviate from their original purpose of improving the quality of human capital in the cooperative sector (Yusof, 2017). Similarly, Kamal et al., (2015) argues that training and education are important elements for enhancing the effectiveness of organizations, relevant parties such as the Malaysian Cooperative Commission, Malaysian Cooperative College, Space (Apex Cooperation Agency) and the movement itself. Should work together to provide many useful and effective design training programs. This will ensure a skilled and knowledgeable cooperative community for the future growth of the country.

Space Support, acting as the co-operative body of the cooperative, is a middleman in the supply of raw materials that indirectly enables cooperatives to control market prices (Najma et al., 2015). Relationships with suppliers are important to get stock supply out of stock and wait a long time to re-supply. Moreover, the geographical factors of Sabah are far from the Space. Studies (Centenaro \& Laimer, 2016) show that the relationship between the supermarket sector and the suppliers positively affects the success of the sector. 
INTERNATIONAL JOURNAL OF ACADEMIC RESEARCH IN BUSINESS AND SOCIAL SCIENCES Vol. 10, No. 9, 2020, E-ISSN: 2222-6990 @ 2020 HRMARS

\section{Methodology}

This study used quantitative methods. The population of this study is all members of the School Cooperative Board consisting of all teachers and non-teaching staff (KTBM) in which they are experts in decision making as compared to CBM students who are only assistants to CBM teachers. The overall target population of this study was 504 people comprising 84 cooperatives earning over RM 100,000 from all secondary schools in Sabah. The sampling method used in this study is a stratified random (multiple) sampling method because it involves a large geographical area and large population size. Structural random sampling, involving the stratification or separation process, followed by simple random subject selection from each survey layer (Sekaran \& Bougie, 2016). With 7 constructs and the number of items in each construct more than three items this study requires only at least 150 samples (Hair et al., 2010).

This study used questionnaire instruments modified by the researchers themselves based on the questionnaire (Jamilah et al., 2012; Zahirudin, 2011, \& Maimon et al., 2010). In total, the questionnaire was divided into nine sections according to the variables determined by the researcher. The Likert scale of 1 to 7 is a measure of the uniformity of an instrument, enabling it to be analyzed with SPSS software to test the hypothesis of the study (Kamal et al., 2015). Self-administered questionnaires were used for data collection and were reviewed after pre-test. 300 copies of the questionnaire were distributed, and 250 copies were returned. 217 copies were considered usable because 33 copies were found incomplete. With a response rate of over 70 percent indicates nonresponse errors need not be mitigated (Nulty, 2008).

All data obtained in this study were processed using Statistical Package for Social Science (SPSS) software version 21. Next, statistical inference analysis, using Structural Equation Model (SEM) was performed to draw conclusions about the population from the sample. Specifically, Structural Equation Modeling (SEM) was performed to test a set of relationships between independent variables and dependent variables (Ghazali \& Hussin, 2018; \& Zainuddin, 2012) as suggested in the research hypothesis.

\section{Results}

This study shows that the motivational impact of school cooperative business performance is positive and significant. This means that the more positive the motivation of a school co-manager (CBM) is, the better the performance of the school's cooperative business. This is because motivation can motivate a person to take the action he or she wants to take (Kotler \& Keller, 2016). The findings of this study are in line with other findings of Agus (2006); Suryono (2006); Syafri et al., (2015); Mustapa Kamal et al., (2015); Andjarwati, (2015); Prasetyaningrum (2020); positively and significantly influenced work but all studies did not focus on the performance of the school cooperative business. In line with this, the study focused on the motivational impact of work on school cooperative business performance.

Overall, job motivation factors directly influenced the performance of the school cooperative business by $44 \%$ while the other factors were not examined in this study. The following is an illustration of the effect of the factors of work motivation on the performance improvement of the school cooperative business created in this study. 
INTERNATIONAL JOURNAL OF ACADEMIC RESEARCH IN BUSINESS AND SOCIAL SCIENCES Vol. 10, No. 9, 2020, E-ISSN: 2222-6990 @ 2020 HRMARS

Figure 1: Effects of work motivation factors on cooperative performance

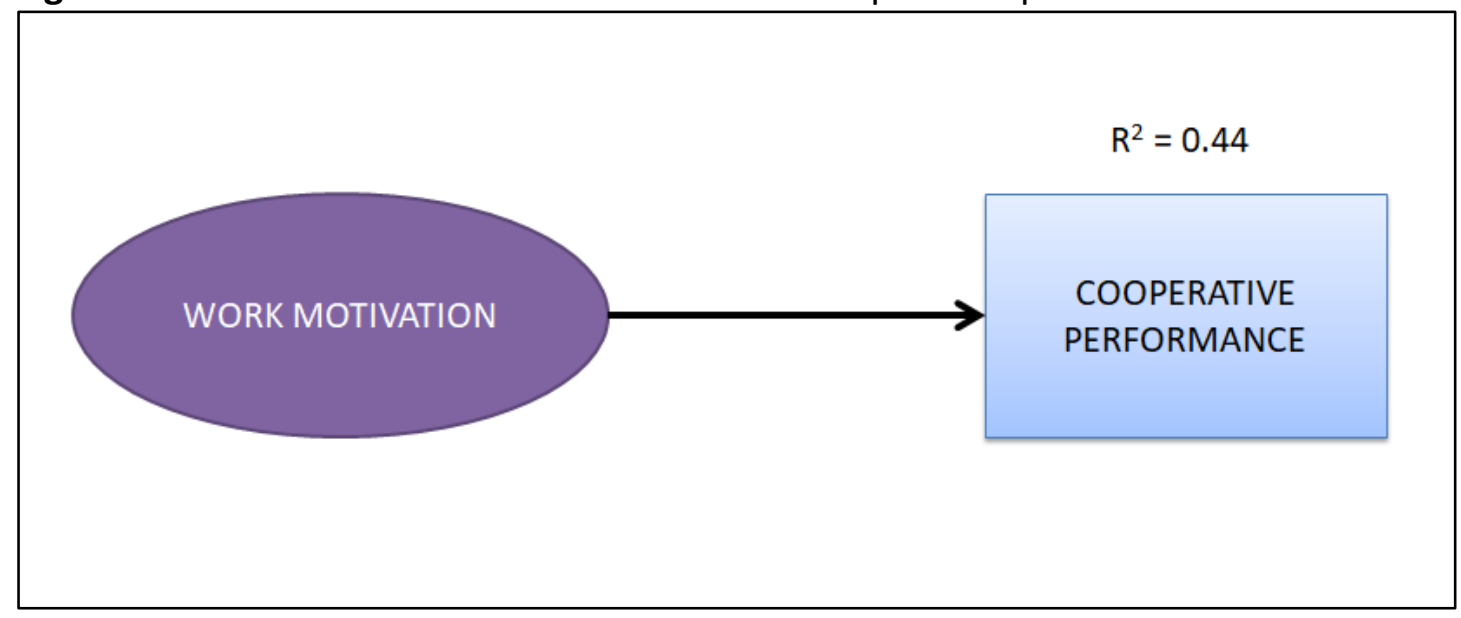

\section{Discussion and Conclusion}

This study shows that the influence of motivation on the business performance of school cooperatives is positive and significant. This means that the more positive the motivation of a school cooperative manager, the better the business performance of the school cooperative. This is because motivation can motivate a person to take the action he or she wants to take (Kotler \& Keller, 2016). The motivation factor of this work has also affected the performance of the cooperative by $44 \%$ while the rest are from other factors not studied in this study. Therefore, this study is very important for all school administrators who own cooperatives to take into account the impact of work motivation of cooperative managers as Cooperative Board Members (CBM) who are responsible in determining the direction of school cooperatives. They should take the initiative in increasing the work motivation of the cooperative managers as well as the responsible of CBM.

To increase work motivation, a manager must create the right climate in which employees can grow to their full potential (Eravala et al., 2019). Failure to provide such a climate would theoretically increase employee frustration and could lead to lower performance, lower job satisfaction, and lower organizational productivity (Rafikul \& Ahmad, 2008). Thus, employees with high internal motivation will always work hard without being forced or directed to carry out their responsibilities (Chiang \& Jang, 2008).

At the school level, teachers as managers always face time constraints to teach with the time to take care of cooperative affairs. Therefore, the administrator should give special time for the manager (teacher) to carry out their duties as a cooperative manager. In this case, the school administrator can make the position of school cooperative manager as a valid position in the daily assignment as a teacher and also as a cooperative manager. In this way the teachers who manage the cooperative will be more motivated.

Furthermore, motivated employees will be better prepared to do the job they are given. In other words, the higher the motivation they have, the higher the productivity they will generate (Nimusima \& Tumwine, 2017). For the managers of the internally motivated co-operatives, they will act on their own to better manage their work especially in their organizational activities (Antonios, 
INTERNATIONAL JOURNAL OF ACADEMIC RESEARCH IN BUSINESS AND SOCIAL SCIENCES

Vol. 10, No. 9, 2020, E-ISSN: 2222-6990 @ 2020 HRMARS

2014). This will directly make the employee without the need for serious supervision due to their enthusiasm and desire to work rather than external rewards (Ankli et al, 2014).

\section{References}

Abdul Fatah, A. (2016). Seminar pentadbiran dan pengurusan koperasi sekolah negeri Kelantan. Angkasa.

Agus, S. (2006). Pengaruh motivasi kerja, kepemimpinan, dan budaya organisasi terhadap kepuasan kerja karyawan serta dampaknya pada kinerja perusahaan. PT. Pei Hai International Wiratama Indonesia.

Andjarwati, J. (2015). Motivasi dari sudut pandang Teori Hirarki Kebutuhan Maslow, Teori Dua Faktor Herzberg, Teori X Y Mc Gregor, dan Teori Motivasi Prestasi Mc Clelland. Jurnal IImu Ekonomi \& Manajemen, 1, 45-54.

Ankli, R. E., Palliam, R., Ankli, R. E., \& Palliam, R. (2014). Feature articles enabling a motivated workforce: Exploring the sources of motivation.

https://doi.org/10.1108/14777281211201169

Antonios, P. (2014). Enhancing staff motivation in "tough" periods: Implications for business leaders. https://doi.org/10.1108/SD-05-2014-0060

Azman, A. R., Yazis, M. A. B., Noorizzuddin, M. N., \& Mahdir, A. (2016). Program usahawan bagi memperkasa ekonomi golongan asnaf: Pemantauan dari Aplikasi Myema. Pengurusan, Jurnal Fatwa, Penyelidikan, 7, 29-38.

Alhafidz, A., Jati, K., \& Yusman, Y. ( 2015). The effectiveness of training programs among co-operative members in Sarawak. Malaysian Journal of Cooperative Study, 11, 45.

Bartol, K. M., and Martin, D. C. (1998), Management, 3rd ed., McGraw-Hill, New York, NY.

Centenaro, A., \& Laimer, C. G. (2016). Cooperative relationships and competitiveness in supermarket sector. Review of Business Management, 19(63), 65-81.

https://doi.org/10.7819/rbgn.v0i0.3070

Chiang, C.-F., \& Jang, S. (Shawn). (2008). An expectancy theory model for hotel employee motivation. International Journal of Hospitality Management, 27, 313-322.

Coda, R., Krakauer, P. V. de C., \& Berne, D. de F. (2017). Are small business owners entrepreneurs? Exploring small business manager behavioral profiles in the Sao Paulo Metropolitan region. Revista de Administração. https://doi.org/10.1016/j.rausp.2017.05.011

International Law Book Services. (2018). Cooperative Act (1993) (Act 502) \& regulation. Petaling Jaya.

Dimas, K. (2011). Pengaruh karateristik individu, karateristik pekerjaan dan budaya organisasi terhadap kepuasan kerja karyawan yang dimedatasi motivasi kerja. University Muhammadiyah Purwokerto.

Eravala, K., Henttonen, K., \& Lampela, H. (2019). Entrepreneurial competencies in successfully innovative SMEs. International Journal Of Entrepreneurship And Small Business, 38(3), 251. doi: 10.1504/ijesb.2019.103428

Fasasi, Y. A., Etejere, P. A. O. E., \& Oyeniran, S. (2016). Malaysian online journal of maximum job performance in Nigerian Higher. Malaysian Online Journal of Educational Management, 4(1), 32-43.

Ghazali, D., \& Hussin, S. (2018). Metodologi penyelidikan dalam pendidikan (2nd ed.). Universiti Malaya.

Hair, J. F., Black, W. C., Babin, B. J., \& Anderson, R. E. (2010). Multivariate data analysis with reading 
INTERNATIONAL JOURNAL OF ACADEMIC RESEARCH IN BUSINESS AND SOCIAL SCIENCES Vol. 10, No. 9, 2020, E-ISSN: 2222-6990 @ 2020 HRMARS

(Seven Ed). Englewood Cliffs, NJ: Prentice Hall.

International Co-operative Alliance. (2017). Co-operatives \& the enabling environment: Key findings. https://www.ica.coop/en/media/library/doing-co-operative-business-report-0

Jamilah, D., Noranita, M. N., Rashid, R., \& Yusuf, M. I. (2012). Analisis kompetensi anggota lembaga koperasi sekolah dalam 100 buah koperasi sekolah-sekolah Gred A. Pusat Pengurusan Dan Inovasi, Maktab Kerjasama Malaysia, 62.

Karthikeyan, M. (2011). Indicator of good governance practices in self employed womens Saccos Union in Addis Ababa, Ethopia-An Exploratory Study. Malaysian Journal of Cooperative Study, 7, 74.

Karunakaran, R., Brehanu, B., \& Ahmedin, S. (2011). Determinants of co-operatives members participation in input and output marketing by multi purpose co-operatives. Malaysian Journal of Cooperative Study, 7, 15-36.

Kasino, K., \& Indrayanti, N. (2020). Analisis pengaruh motivasi kerja, gaya kepimpinan, disiplin kerja terhadap kinerji kerja karyawan Pt. Siantar Top Waru-Sidoarjo. Ecobisma. Jurnal Ekonomi, Bisnis dan Manajemen, 7(1), 20-30. doi: 10.36987/ecobi.v7i1.1512

Kotler, P., \& Keller, K. L. (2016). A framework for marketing management. (S. Wall, Ed.). Pearson Education Limited.

Lasrado, F., Gomiseck, B., \& Christopher, U. (2017). Effectiveness of employee suggestion schemes from critical success factors to outcomes. International Journal of Quality and Service Sciences, 9(1), 120-136. https://doi.org/https://doi.org/10.1108/IJQSS-08-2016-0058

Luthans, F. (1998). Organizational Behavior. 8th Edition, Irwin McGraw-Hill, Boston.

Maslow, A. H. (1970). Motivation and Personality (2nd ed.). New York: Harper \& Row.

McClelland, D. C. (1985). Human motivation. Glenview, IL: Scott, Foresman.

Ali, M. H., \& Marzuki, A. I. (2017). Proses pemantapan tadbir urus koperasi sekolah. (1st ed.). Petaling Jaya, Selangor.: Angkatan Koperasi Malaysia Berhad.

Ali, M. H., \& Marzuki, A. I. (2016). Ke arah memantapkan perniagaan koperasi sekolah. (1st ed.). Angkatan Koperasi Malaysia Berhad. [tiada dalam citation].

Mohd. Yusof, K . (2017). Temubual. INFO, Maktab Koperasi MalaysiaKM, pp. 27-28

Zamri, M. Y. (2012). Peranan dan strategi Angkasa dalam meningkatkan kopemtesi anggota koperasi. Pusat Penyelidikan Pengurusan dan Inovasi. Maktab Koperasi Malaysia.

Yusof, M. K. (2017). Temubual. Info, Maktab Koperasi Malaysia, 27-28.

Mujah, W., Ruziana, R., Samad, A., Singh, H., \& Cruz, O. T. D. (2011). Meaning of work and employee motivation. Terengganu International Management and Business Journal, 1(2), 18-26.

Kamal, M., Norsaadah, M., \& Abdul Jumaat, M. (2015). The resilience concept of Islamic entrepreneur and the promoting of Islamic financing products to credict cooperatives in Malaysia. Malaysian Journal of Cooperative Study, Maktab Kerjasama Malaysia, 11, 25.

Najma, N., Nusi, M. A. R., \& Shafeeza, N. S. (2015). Penglibatan dan prestasi koperasi dalam sektor perumahan di Malaysia. Malaysia Cooperative Journal, 10, 49-64.

Nimusima, P., \& Tumwine, J. F. (2017). Assessing the relationship between employee motivation and productivity in Rwanda's Nyagatare district. Frontiers in African Business Research, 221-235.

Zita, N. M. R., Haslinda, S., Nurol'ain, M., Safa'ai, M. S., \& Ruzilah, A. M. (2014). Amalan perancangan strategik dalam kalangan koperasi di Malaysia. Malaysian Journal of Cooperative Study, Maktab Kerjasama Malaysia, 10, 70-98. 
INTERNATIONAL JOURNAL OF ACADEMIC RESEARCH IN BUSINESS AND SOCIAL SCIENCES Vol. 10, No. 9, 2020, E-ISSN: 2222-6990 @ 2020 HRMARS

Bazilah, N. S., Sabri, A., Jusoh, Y., \& Mustafa, M. (2013). Model regresi logistik dan rangkaian neural: Suatu perbandingan dalam mengukur kerugian koperasi. Malaysia Cooperative Journal, 9, 7790.

Nulty, D. D. (2008). The Adequacy of Response Rates to Online and Paper Surveys: What Can Be Done? Assessment \& Evaluation in Higher Education, 33, 301-314. https://doi.org/10.1080/02602930701293231

Owens, M. (2014). Train to sustain. Tarining Journal, 34-39.

Pauline, R. (2017). Interaction between managerial competencies and leadership in business organisations. https://doi.org/http://dx.doi.org/10.15181/rfds.v21i1.1412

Prasetyaningrum, D. (2020). Pengaruh komitmen organisasi, karakteristik pekerjaan terhadap kepuasan kerja karyawan dan motivasi kerja sebagai variabel intervening. MANAJERIAL, 7(2), 155. doi: 10.30587/manajerial.v7i2.1498

Pusat Penyelidikan dan Inovasi. (2014). Peruncitan dan Pemborongan' di Norge Coop, Oslo, Norway. In Seminar Perkongsian Hasil Penyelidikan \& Kisah Kejayaan Koperasi (p. 133). Ipoh.

Rafikul, I., \& Zaki, A. H. I. (2008). Employee motivation: A Malaysian perspective. International Journal of Commerce and Management, 18(4), 344-362. https://doi.org/https:// doi.org/10.1108/10569210810921960

Rahimah, A. S. (2011). Kekuatan koperasi. Dimensi Koop Maktab Koperasi Malysia, 24-31.

Maimon, R. Y., Norwatim, A. L., Rasydi, M. A. R., Diana, A., Hayati, N. A. R., \& Ju Samsuddin, S. (2010). Penerimaan produk bumiputera di hypermarket. Pusat Pengurusan Penyelidikan dan Inovasi. Maktab Koperasi Malaysia.

Rohaida, M. D., \& Razaleigh, M. K. (2014). Penilaian kepada koperasi sekolah dalam membentuk gaya kepimpinan pelajar satu kajian awalan. Al - Hikmah, 6, 107-121.

Ruziana, R. S., \& Zurina, S. (2015). Education's role in co - operative sector : Issues, challenge and prospect, Nama Jurnal, volume(1), 24-28.

Rosmimah, M. R., Maimon, R. Y., Rahimah, A. S., \& Hasrin, A. H. (2011). Co-operative as indicator of organizational integrity. Malaysian Journal of Cooperative Study, volume (issue), no. page.

Sekaran, U., \& Bougie, R. (2016). Research methods for business (7th ed.). United Kingdom: John Wiley \& Sons Ltd.

Rohaya, S. W. I., Meol, F. A., \& Suandi, M. (2013). Faktor-faktor kritikal kejayaan perniagaan kedai runcit koperasi di negeri Sarawak. Malaysia Cooperative Journal. 9, 93.

Suryono, W. (2006). Analisis pengaruh gaya kepemimpinan, motivasi dan lingkungan kerja terhadap kinerja karyawan. Jurnal Ilmu Ekonomi \& Manajemen, volume (issue), no. page.

Syafri, M., Jusoh, A., Sukati, I., Othman, M. F., \& Nor, K. M. (2015). Kesan moderator kearifan tempatan dalam mempertingkatkan prestasi pekerja di Indonesia. Jurnal Pengurusan, 44, 149-165.

Universiti Kebangsaan Malaysia. (2014). Pengaruh kompetensi kecerdasan emosi terhadap tingkah laku kepemimpinan transformasi gerakan koperasi sekolah di sekolah-sekolah menengah negeri Selangor. (Ph.D)

Zafir, M. M., Mohd. Hizam, H., \& Fazilah, M. H. (2012). Pengurusan organisasi. (Ruzita R., Ed.) (2nd ed.). Cengage Laerning Asia Pte.

Zahirudin, A. (2011). Faktor kejayaan industri kecil \& sederhana (IKS) dalam sektor perkilangan di Malaysia. Universiti Pendidikan Sultan Idris.

Zainuddin, A. (2012). A handbook on SEM. UTM Kelantan. 